\title{
Diseases and parasites of rafted mussels (Mytilus galloprovincialis Lmk) : preliminary results
}

\author{
A.J. Figueras ${ }^{\mathrm{a}}$, C.F. Jardon ${ }^{\mathrm{b}}$ and J.R. Caldas ${ }^{\mathrm{a}}$ \\ ${ }^{a}$ Institute de Investigaciones Marinas CSIC, Vigo, Eduardo Cabello, 6, 36208 Vigo, \\ Spain \\ ${ }^{\mathrm{b}}$ Colegio Universitario de Vigo, Vigo, Spain
}

\section{ABSTRACT}

Figueras, A.J., Jardon, C.F. and Caldas, J.R., 199 I. Diseases and parasites of rafted mussels (Mytilus galloprovincialis Lmk): preliminary results. Aquaculture, 99: 17-33.

A detailed histopathology-based survey of a total of 330 cultured mussels collected from three locations on mussel rafts in the Ria de Arosa (NW, Spain) -was carried out over a l-year period between 1985 and 1986. The populations were "healthy" at the time of sampling. The commonest parasites found in histology were Rickettsiae (up to 50\% of histological samples demonstrated clear “inclusions”), the Ascetosporan Marteilia (possibly M. maurini) (UP to 35\%), and the “redworm” copepod Mytilicola intestinalis (up to $80 \%$ ). A gill ciliate similar to Ancistrum mytili was found on all samples examined, ranging in frequency from $60-95 \%$. Specific host-tissue reponses were detected in association with the plasmodial and spore stages of Marteilia sp. infections, as well as with ovarian infection by the microsporidian parasite Steinhausia mytilovum, and there was a marked haemocyte encapsulation response to tissue penetration by a copepod. No tissue responses could be detected in association with the other parasites observed.

\section{INTRODUCTION}

The annual production of farmed mussels in Galicia, northern Spain, is approximately 200000 tonnes, which is approximately $50 \%$ of the total world production. Bearing in mind the size of the mussel-culture industry, there are a few documented cases of mass mortalities of mussels (Korringa, 1951; Li and Clyburne, 1979; Munford et al., 1981), and no disease-related mortalities have been recorded, to date, from Galicia. The lack of 
information about diseases and parasites of mussels, relative to the information available for cultivated oyster species, is not, unfortunately, indicative of the overall health status of mussels (Bower and Figueras, 1989). The paucity of information on musses diseases is more a reflection of the relatively recent development of intensive mussel culture and, hence, closer observation and concern over mortalities.

This preliminary note is based upon a detailed histological survey to determine which parasites are present in "healthy" stocks of cultivated mussels and at what levels of infection. This is designed to provide base-line observations for future reference, should a parasite or disease suddenly become a problem in the massive mussel aquaculture region of Galicia.

\section{MATERIALS AND METHODS}

Between June 1985 and February 1986 samples consisting of 30 mussels were collected from commercial mussel rafts from the interior, middle and external areas in the Ria de Arosa of Galicia (Fig. 1). The mussel spat was placed at the same time in the different rafts (November 1985); the difference in growth between the different rafts is not significant.

The external area was sampled in June and December of 1985; the middle area was sampled in June, October and December 1985 and January and February 1986, and the inner area was sampled in October and December 1985 and January and February 1986. The animals were removed from their shells and their condition index recorded (ratio between meat weight and shell length).

The mussels were fixed whole in Davidson's fixative (Shaw and Battle, 1957) for $24 \mathrm{~h}$ and oblique transverse sections, approximately 2-3 mm thick, were taken from each specimen so that mantle, gonad, digestive gland, gills, kidney and foot were included. The tissue samples were embedded in paraffin wax and $5 \mu \mathrm{m}$ sections stained with iron haematoxylin, acid fuschin and aniline blue (Gray, 1954).

Identification of metazoan parasites was done using a dissecting microscope. 
Observations from the histology sections were analysed using a two-way ANOVA comparing histological frequency, of each parasite or disease to the location of the sample of the mussel raft and date of collection. Histological analysis was used since this is the technique best suited for non-specific bivalve pathology surveys. Although this necessarily involves sub-sampling of the sample animals, the purpose of the survey was to find cut what was commonly present. Parasites found in histology within the small sample-sizes collected can be assumed to be present in far larger numbers and at higher prevalences than observed.

\section{RESULTS}

Rickettsiae were detected solely in the epithelial cells of the secondary digestive tubules, and no tissue response to their presence was observed (Fig. 2). The only effect noted was that infected epithelial cells showed slight hyperplasia. There was a significant $(\mathrm{P}<0.05)$ negative correlation between condition index $(-0.599)$ and prevalence of rickettsial infections. In addition there was a slight positive relation between prevalence of rickettsias and length of mussel (Graph 1C).

No significant difference was found between prevalence of rickettsias observed and the location of the mussel raft $(\mathrm{F}=0.253$; d.f. $=2)$. There was, however, a significant difference $(\mathrm{F}=16.9$ 15; d.f. $=4)$ between prevalence of rickettsias observed and date of collection (Graph 2C).

A coccidian parasite, similar to Pseuduklossia sp., was found only in the cells of the kidney, where it was observed to cause slight hyperplasia of the infected epithelial cells. No haemocyte response was elicited by infection with this parasite and prevalence was consistently less than $5 \%$ in the samples examined.

The microsporidian Steinhausia mytilovum (Fig. 3a) was found infecting 7.5-12.5\% of female mussels. It is most easily detected when the female gonads are ripe (spring) and is always accompanied by a strong haemocyte infiltration response (Fig. 3b).

The ascetosporidian Marteilia sp. was found in the epithelial cells of the digestive tubules (Fig. 4a) as well as in the epithelial cells of the stomach (Fig. 4b). The young 
plasmodia found in the stomach wall were associated with tissue disruption, which consisted of massive secretion of mucus and infiltration of haemocytes into the digestive gland. Gonadal development appeared to be retarded in heavily infected individuals compared with non-infected mussels. The significance of this observation, however, could not be evaluated using the sample numbers available. The lowest condition factors were found in mussels demonstrating Marteilia sporulation. Marteilia showed two peaks in prevalence in the sample examined: one in February and one in October (Graph 2D). There appeared to be a decline in prevalence of Marteilia towards the outer mussel rafts; however, there was no statistically significant difference of the prevalence of plasmodial or sporangial stages between different raft locations or the date of sampling.

A gill ciliate similar to Ancistrum mytili was found varying from zero to approximately 300 in one tissue section. Even at the highest densities of infestation, however, no tissue damage could be detected in association with the parasite. There is a significant positive correlation $(r=0.669)$ with the condition index and a negative correlation $(r=-0.406)$ with mussel length (Graph 1A). There was no influence of the date of collection ( $\mathrm{F}=$ 0.291 , d.f. $=4)($ Graph $2 \mathrm{~A})$ or location of the mussel raft $($ Graph 3A) on the prevalence of infestation.

An intracellular ciliate was found in the epithelial cells of the secondary digestive tubules (Fig. 5). These protozoans were pear-shaped, covered with rows of cilia and measured 10-12 $\mu \mathrm{m}$ in length. They were consistently found within the tubule epithelial cells, which is a highly unusual infection site for bivalve ciliates which are most commonly found extracellularly or on the surface of the gills and mantle (Fenchel, 1965). Similar parasites have been observed in blue mussels from eastern Canada (McGladdery, personal communication). Despite their intracellular location, these ciliates do not appear to provoke a specific host response. There was a slight decrease in prevalence of this parasite in mussels from the outer mussel rafts; however, the differences found were not significant (Graph 3E).

The digenean trematode Proctoeces maculatus was only rarely found. The sporocyst stage was found in the digestive gland and no specific tissue reaction was observed. 
The "redworm" copepod Mytilicola intestinalis was the most common parasite found in the mussels examined. In several samples all the mussels were found to contain at least one of these copepods (Fig. 6a). This parasite causes an erosive action with the hooks of the third pair of antennae damaging the epithelial cells of the intestine and inducing a haemocytic infiltration by the host (Fig. 6b). A significant positive correlation ( $\mathrm{r}=$ O.614; $\mathrm{P}<0.05$ ) was found between frequency of infection and length of mussel (Graph 1B) and dates of collection ( $\mathrm{r}=0.421 ; \mathrm{P}<0.05$ ) (Graph 2B). There was no statistically significant difference in the frequency of infection of mussels from different locations of the mussel rafts (Graph 3B).

Another copepod was also found, but at a much lower frequency (0.67). It was found buried in the peripheral connective tissue of the digestive gland and elicits a strong haemocytic encapsulation response. There was no correlation between infection of this parasite and mussel condition.

General histopathological responses, which could not clearly be linked to any detectable pathogenic organism, were also observed. For example, the highest prevalences of the infiltration of the digestive gland (Fig. 7) were found in February and October (Graph $2 F)$ and these differed significantly $(F=5$; d.f. $=4)$ from those found at other dates. There was no significant correlation $(r=-0.058)$ with mussel length (Graph 1E).

Granulocytomas (Fig. 8) were found with a maximum frequency of 6\% and did not appear to be associated with a detectable pathogenic agent. A heavy infiltration of the mussel foot tissue (Fig. 9) was found with low prevalence.

A single case of haemocytic neoplasia was detected (Fig. 10). This resembled the haemocytic “neoplastic disorder” (Alderman et al., 1977) described in flat oyster (Ostrea edulis).

\section{DISCUSSION}

Rickettsial infections in bivalves do not have a clearly defined pathological effect. Some authors (see review of Lauckner, 1983) are of the opinion that they can act as a vector for pathogenic viruses for humans. Pathogenicity for the bivalve host has never been 
demonstrated for mussels. However, hatchery-reared larval bay scallops (Argopecten irradians) have been reported to suffer mortalities due to a related chlamydial organism (Leibovitz, 1989); and Le Gall et al. (1988) have reported rickettsiales-like infections as the possible cause of mass mortalities of the sea scallop Pecten maximus. It appears, therefore, that although rickettsial organisms are not normally associated with pathology, they may have the potential. to become pathogenic to their hosts under adverse conditions, such as artificially high population densities. Bearing in mind the very high densities of mussels currently being grown in Galicia, this parasite should be monitored closely, especially with respect to sporadic mussel “die-offs”.

The parasite Marteilia is known to contain more than one species, and these are almost impossible to distinguish using light microscopy (Camps et al., 1982). During a search for a possible alternative host to the flat oyster for Marteilia refringens, Camps et al. (1979) found what appeared to be stages of the parasite in $2 \%$ of mussels from the Auray and Penze areas of France. Gutierrez (1977) found a prevalence of 3\% infection by Marteilia in 92 mussels sampled from Galicia. It seems likely that the species which these authors were finding was M. maurini, which was identified by Comps et al. (1982) from mussels which had been imported from France to the Venice Lagoon. In the present study the highest prevalences of the plasmodial stages were found in February (Graph 2D). The seasonal dynamics of this parasite are currently under investigation. The pathogenic potential of Marteilia refringens for flat oyster is well documented (Comps, 1985); however, that for M. maurini is as yet unknown. Given the apparent retardation of mussel gonad development, in addition to the extensive host haemocyte response observed, it appears possible that this parasite could develop into a serious pathogen, especially under adverse growing conditions or stressful management (e.g., repetitive handling).

The ovarian parasite Steinhausia mytilovum which was found in less than 5\% of the mussels sampled from Galicia, has been reported from mussels collected along the eastern U.S. (Field, 1923; Sprague, 1965, 1970) and also from mussels collected from the Bay of Naples (Lauckner, 1983 ). The pathogenic significance of this parasite has not been clearly established (see review Lauckner, 1983); however, there is a definite host haemocyte response to infection and the viability of infected ova is highly questionable. Should the prevalence or intensity of this parasite increase, it has the 
potential to become a significant factor affecting mussel fecundity. In addition, S. mytilovum could become a significant problem to the future development of hatcheryproduced seedstock.

Proctoeces maculatus was reported by Canzonier (1972) from two very weak mussels which had been transported to Italy from the Kia de Arosa in Spain. The sporocyst stage of the parasite was found to be blocking the peripheral arteries of the mantle, as well as distending the filaments of the gills. They were also found in the pallial sinus, where they confer a dark orange colour to the gross appearance of the tissues, hence the label “orange sickness” (Lauckner, 1983). The ability of this parasite to complete its lifecycle within the mussel-host (Stunkard and Uzmann, 1959) means that usually subpathogenic infections could be reasonably expected to be exacerbated to a pathogenic level under confined growing conditions. The ability of the parasite to replace the gonadal tissue of larger mussels is well documented (Lang and Dennis, 1976); however, the levels of infection found in the mussels sampled for the present survey did not reach those reported for mussels elsewhere (Lauckner, 1983). The known potential pathogenic effects of this parasite, however, mean that its prevalence and intensity of infection in the mussel-growing areas of Galicia should be closely monitored.

The commonest parasite found in the present survey was the copepod Mytilicoli intestinalis. The actual pathogenic effects of this parasite are not well understood, but are frequently speculated to be significant (see review Lauckner, 1983; pp. 824-826). The present findings of high prevalences and intensities of $\mathrm{M}$. intestinalis in apparently healthy mussels support the observation of previous authors (Lauckner, 1983) that whereas Mytilicola persists in high numbers in certain areas, there are few if any cases of mass mortalities in their mussel hosts. This also reinforces the opinion of Dollfus (1951) that Mytilicola is not the direct cause of pathogenicity in mussels. The probability persists, however, that $\mathrm{M}$. intestinalis could be a debilitatory factor under adverse growing conditions, based on the close association with the mussel's digestive system. For this reason, the current subpathogenic existence of this copepod may still be worth monitoring, especially in the intensively cultivated areas of Galicia. 
Dissections under the dissecting microscope are being done in order to clarify the possibility of a necrotic metacercarian being the origin of the detected foot infiltration.

The results from this survey clearly indicate that the negligible mussel mortalities encountered in the intensive mussel culture areas of Galicia are not indicative of a parasite-free mussel population. In fact, the mussels are relatively heavily infected by certain species, such as M. intestinalis.

The reason for the low mortality status of these mussels, despite their intensive cultivation, may be attributable to the relatively short time required for the mussels to reach market size ( $9 \mathrm{~cm}$ in length), compared to most other cultivated bivalves. If the grow-out period had to be extended, it might be expected that the heavy parasite burden and the high culture density would have a negative effect.

\section{ACKNOWLEDGEMENTS}

I would like to thank Mr. J. Montes for providing mussel samples from Ria de Arosa. This research was generously funded through a postdoctoral fellowship from Comision Asesora Investigacion Cientifica y Tecnica and by a Research Project Grant \# 87064 from Secretaria Estado Universidad Investigacion - Consejo Superior Investigaciones Cientificas of Spain. The authors also wish to thank Dr. SE. Ford, W.J. Canzonier and Dr. S.E. McGladdery for their help, and two anonymous reviewers for critically reading an earlier draft of the manuscript and offering many helpful suggestions. I (A.J.F.) would like to offer this work in memoriam of Dr. Sung Y. Feng for his encouragement at the beginning of my work in the field of shellfish pathology.

\section{REFERENCES}

Alderman, D.J., Van Banning, P. and Perez Colomer, A., 1977. Two European oyster (0strea edulis) mortalities associated with an abnormal haemocytic condition. Aquaculture, 10: 335-340.

Bower, SM. and Figueras, A.J., 1989. Infectious diseases of mussels, especially pertaining to mussel transplantation. World Aquacult., 20 (4): 89-93. 
Canzonier, W., 1972. Cercaria tenuans, larval trematode parasite of Myth and its significance in mussel culture. Aquaculture, 1: 267-278.

Comps, M., 1985. Digestive Gland Disease of the Fiat Oyster. Fiche No. 19, ICES Fiches for the Identification of Diseases and Parasites of Fish and Shellfish. C.J. Sindermann (Editor), CIEM, Copenhagen, 4 pp.

Comps, M., Grizei, H., Tige, G. and Duthoit, J.L., 1979. Parasites nouveaux de la glande digestive des mollusques marins Mytilus edulis L. et Cardium edule L. C.R. Hebd. Sbanc. Acad. Sci., Paris (Ser. D), 281: 179-181.

Comps, M., Pichot, Y. and Papagianni, P., 1982. Recherches sur Marteilia maurini n.sp., parasite de la moule Mytilus galloprovincialis Lmk. Rev. Trav. Inst. (Sci. Tech.) Pech. Marit., 45: 211-214.

Dollfus, R.P., 1951. Le copépode Mytilicola intestinalis A. Steuer peut-il etre la cause d'une maladie epidemique des moules? Rev. Trav. Off. (Sci. Tech.) Pech. Marit., 17 (2): 8 l-84.

Fenchel, T., 1965. Ciliates from Scandinavian molluscs. Ophelia, 2: 71-73.

Field, LA., 1923. Biology and economic value of the sea mussel Mytilus edulis. Bull. Bur. Fisheries, Wash. (1921-22), 38: 127-259.

Gray, P., 1954. The Microtomists Formulary and Guide. Blakiston, New York, NY, 749 pp.

Gutierrez, P., 1977. Nota sobre marteiliasis en el mejillon Mytilus edulis (L.) de la costa noroeste de España. Invest. Pesq., 41: 637-642.

Korringa, P., 195 I. Le Mytilicola intestinalis Steuer (Copepode parasitica) menace l’industrie mouliere en Zelande. Rev, Trav. Off. (Sci. Tech.) Pech. Marit., 17 (2): 913.

Lang, W.H. and Dennis, E.A., 1976. Morphology and seasonal incidence of infection of Procotoeces maculatus (Looss, 1901) Odhner, 1911 (Trematoda) in Mytilus edulis L. Ophelia, 15: 65-75.

Lauckner, G., 1983. In: 0. Kinne (Editor), Diseases of Marine Animals, Vol. 2. Introduction, Bivalvia to Scaphopoda. Biologische Anstalt Helgoland, Hamburg, pp. 477-1038.

Le Gall, G., Chagot, D., Mialhe, E. and Grizel, H., 1988. Branchial Rickettsiales-like infection associated with a mass mortality of sea scallop Pecten maximus. Dis. Aquat. Org., 4: 229-232. 
Leibovitz, L., 1989. Chlamydiosis: a newly reported serious disease of larval and postmetamorphic bay scallops Argopecten irradians (Lamarck). J. Fish Dis., 12 (2): 125-136.

Li, M.F. and Clyburne, S., 1979. Mortalities of blue mussel (Mytilus edulis) in Prince Island. J. Invert. Pathol., 33: 108-110.

Munford, J.G., Da Ros, L. and Strada, R., 198 1. A study on the mass mortality of mussels in the Laguna veneta. 9. World Maricult. Soc., 12 (2): 186-l 99.

Shaw, B.L. and Battle, H.I., 1957. The gross and microscopic anatomy of the digestive tract of the oyster Crassostrea virginica (Gmelin). Can. J. Zool., 35: 325-346.

Sprague, V., 1965. Observations on Chytridiopsis mytilovum (Field), formerly Haplosporidium mytilovum Field (Microsporida?). J. Protozool., 12: 385-389. Sprague, V., 1970. Some protozoan parasites and hyperparasites in marine bivalve molluscs. In: SF. Snieszko (Editor), A Symposium on Diseases of Fishes and Shellfishes. American Fishery Society, Washington, Special Publication, No. 5, pp. 511-526.

Stunkard, H.W. and Uzmann, J.R., 1959. The life-cycle of the digenetic trematode, Proctoeces maculatus (Looss, 1901) Odhner, 1911 [syn. P. subtenuis (Linton, 1907) Hanson, 1950] and description of Cercaria adranocerca n.sp. Biol. Bull. Mar. Biol. Lab., Woods Hole, 116: 184-193. 
Fig. 1. Sampling locations in the Ria de Arosa used for this survey.

Fig. 2. Rickettsiae in the cells of the secondary digestive tubules (scale bar $=10 \mu \mathrm{m}$ ).

Fig. 3a. Steinhausia mytilovum infection of the ova of mussels (scale bar $=5 \mu \mathrm{m}$ ).

Fig. 3b. Haemocyte infiltration response elicited by Steinhausia myrilovum infection of the mussel ova (scale bar $=20 \mu \mathrm{m}$ ).

Fig. 4a. Marteilia sp. within the digestive tubule epithelia (scale bar $=10 \mu \mathrm{m}$ ).

Fig. 4b. Marteilia sp. within the epithelial cells of the stomach where it appears to be associated with ciliary disruption (scale bar $=10 \mu \mathrm{m}$ ).

Fig. 5. Intracellular ciliate found within the digestive tubule epithelial cells (scale bar $=$ $10 \mu \mathrm{m})$.

Fig. 6a. Transverse section through mussel intestine showing several Mytilicola intestinalis specimens. Note hook penetration of the intestine wall (scale bar $=50 \mu \mathrm{m}$ ).

Fig. 6b. High power magnification showing damage to intestinal epithelia by book penetration and haemocytic response (scale bar $=75 \mu \mathrm{m})$.

Fig. 7. Haemocyte infiltration of the connective tissue of the digestive gland (scale bar $=$ $15 \mu \mathrm{m})$.

Fig. 8. Massive granulocytoma within the connective tissue of the mantle (scale bar $=$ $100 \mu \mathrm{m})$.

Fig. 9. Haemocyte infiltration of the muscle tissue of the foot (scale bar $=25 \mu \mathrm{m}$ ).

Fig. 10. Haemocytic neoplasia in the mantle (scale bar $=10 \mu \mathrm{m})$.

Graph 1. Relation of different diseases and parasites with age (length). 
Graph 2. Influence of the month on the prevalence of different diseases and parasites.

Graph 3. Influence of the location of the sample on the prevalence of different diseases and parasites. I, internal; M, middle; E, external area. 


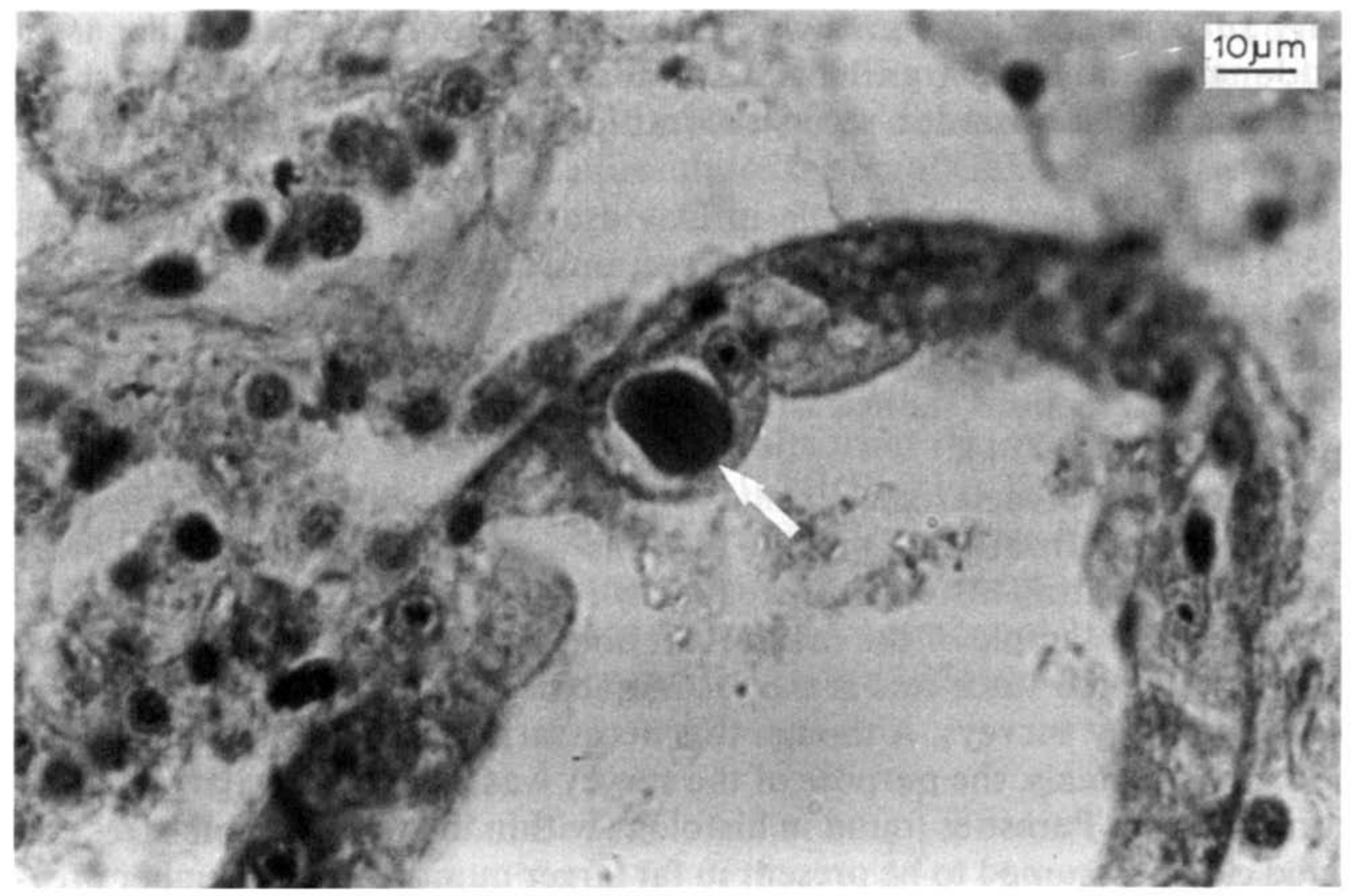

Fig. 2 

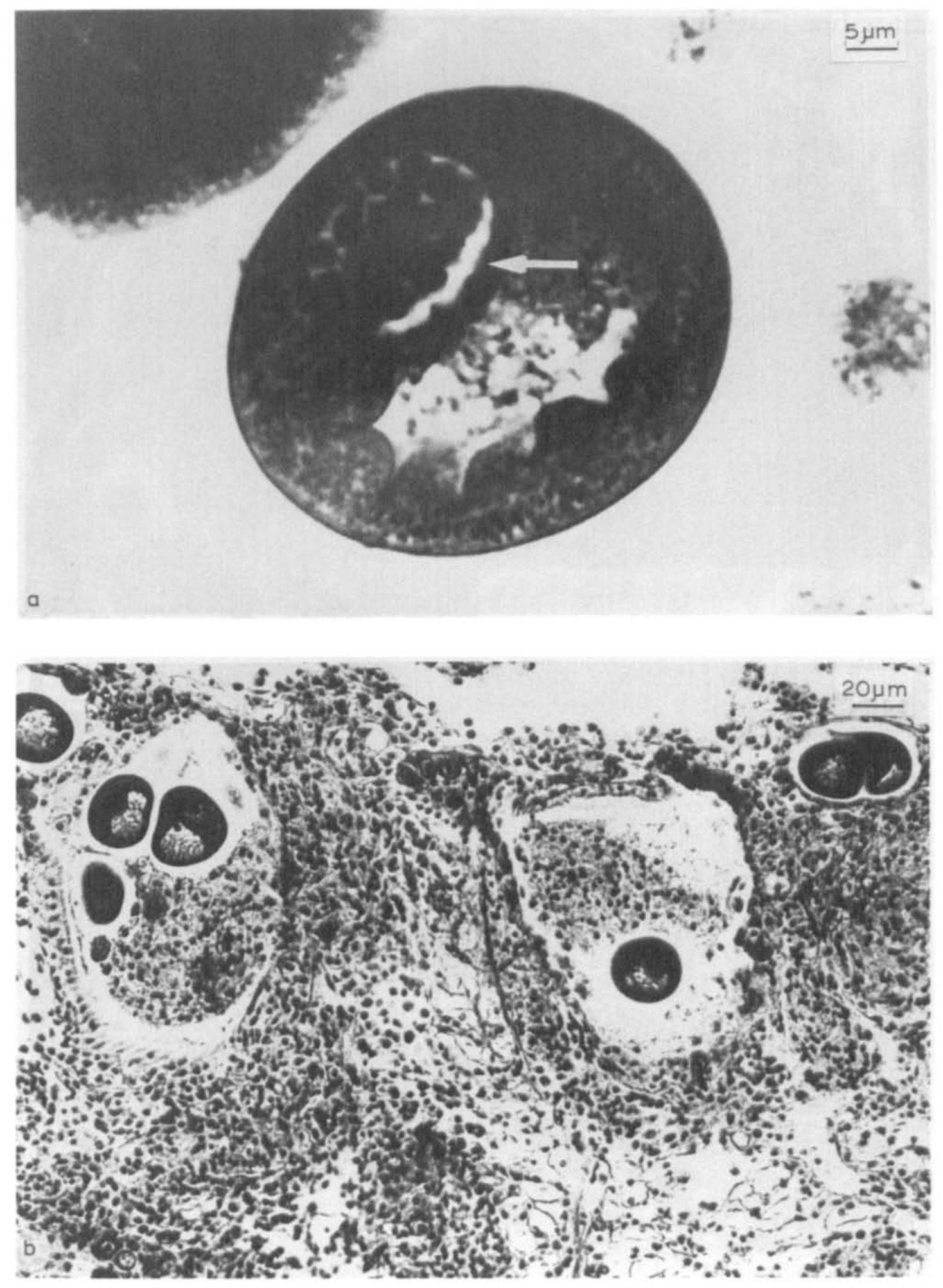

Fig. 3a, 3b 

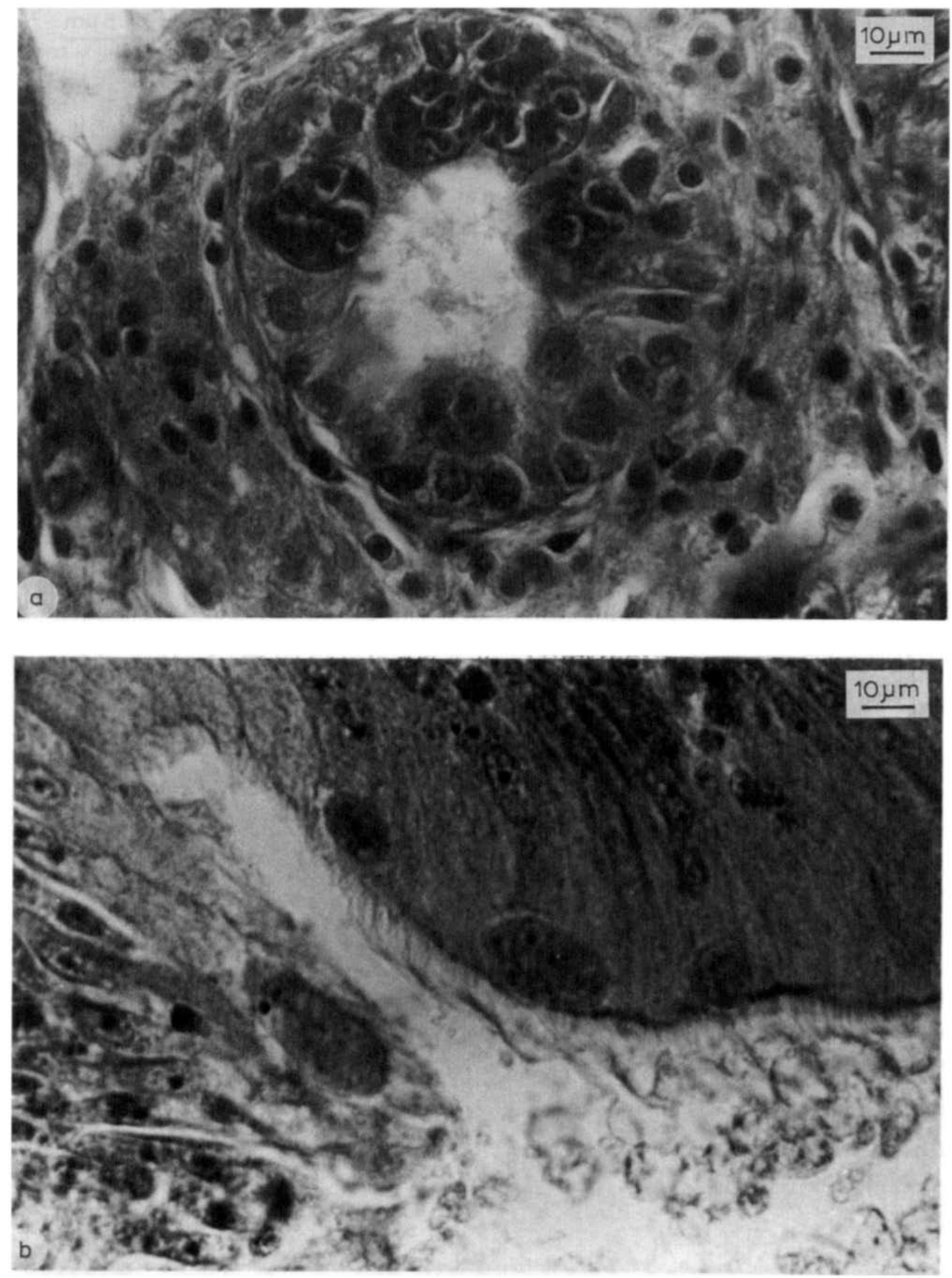

Fig. 4a, 4b 


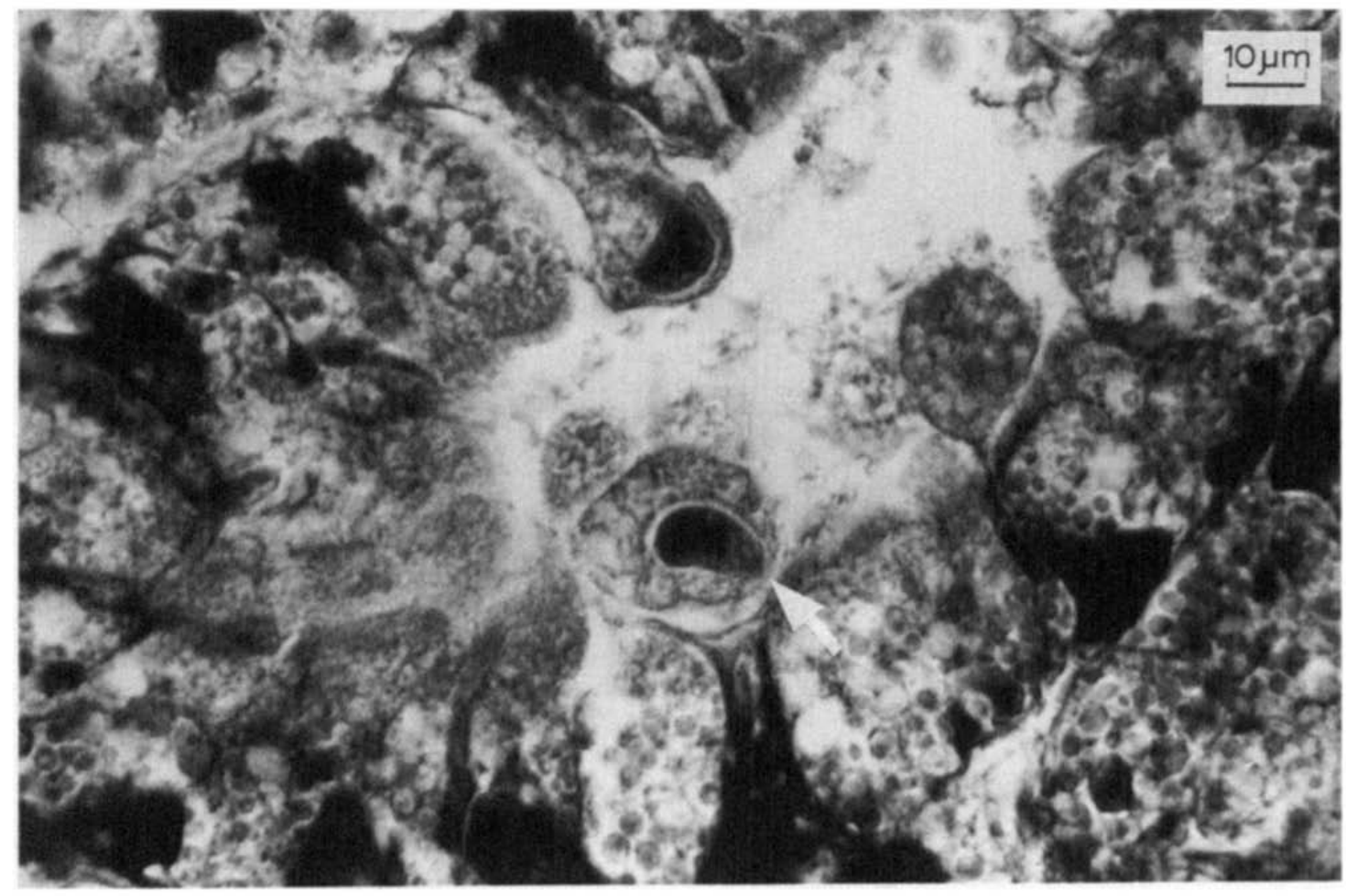

Fig. 5 

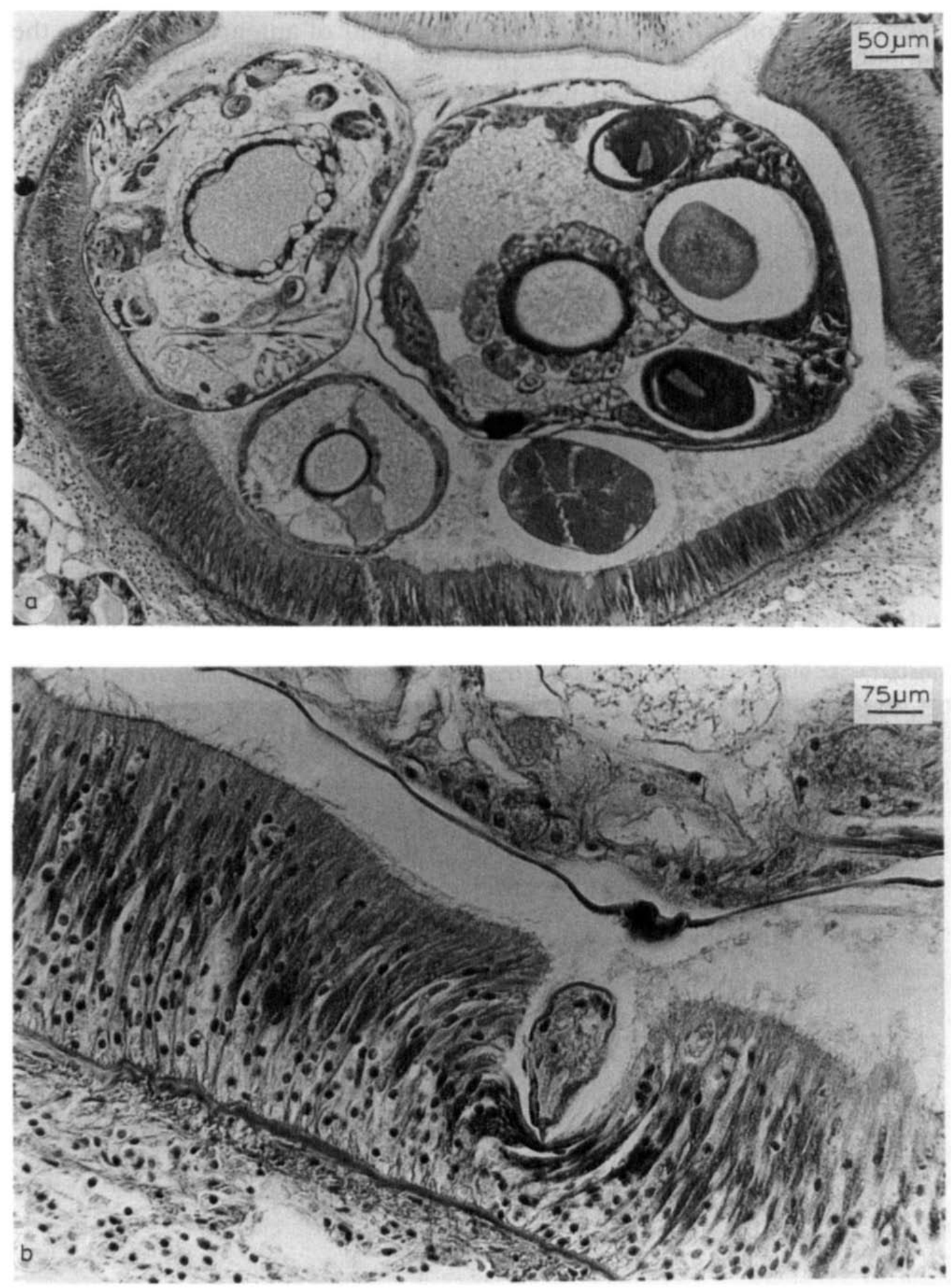

Fig. 6a, 6b 


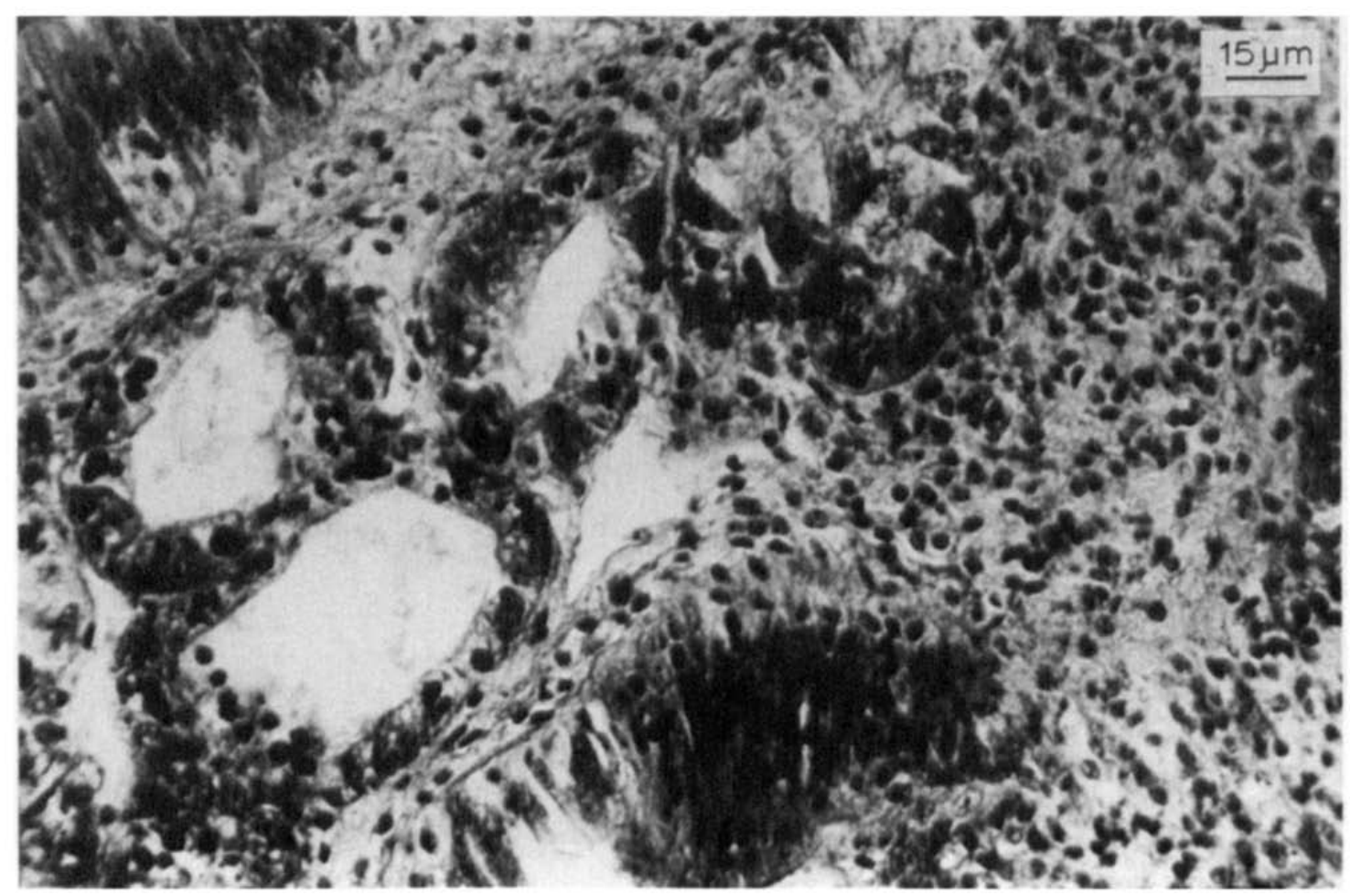

Fig. 7

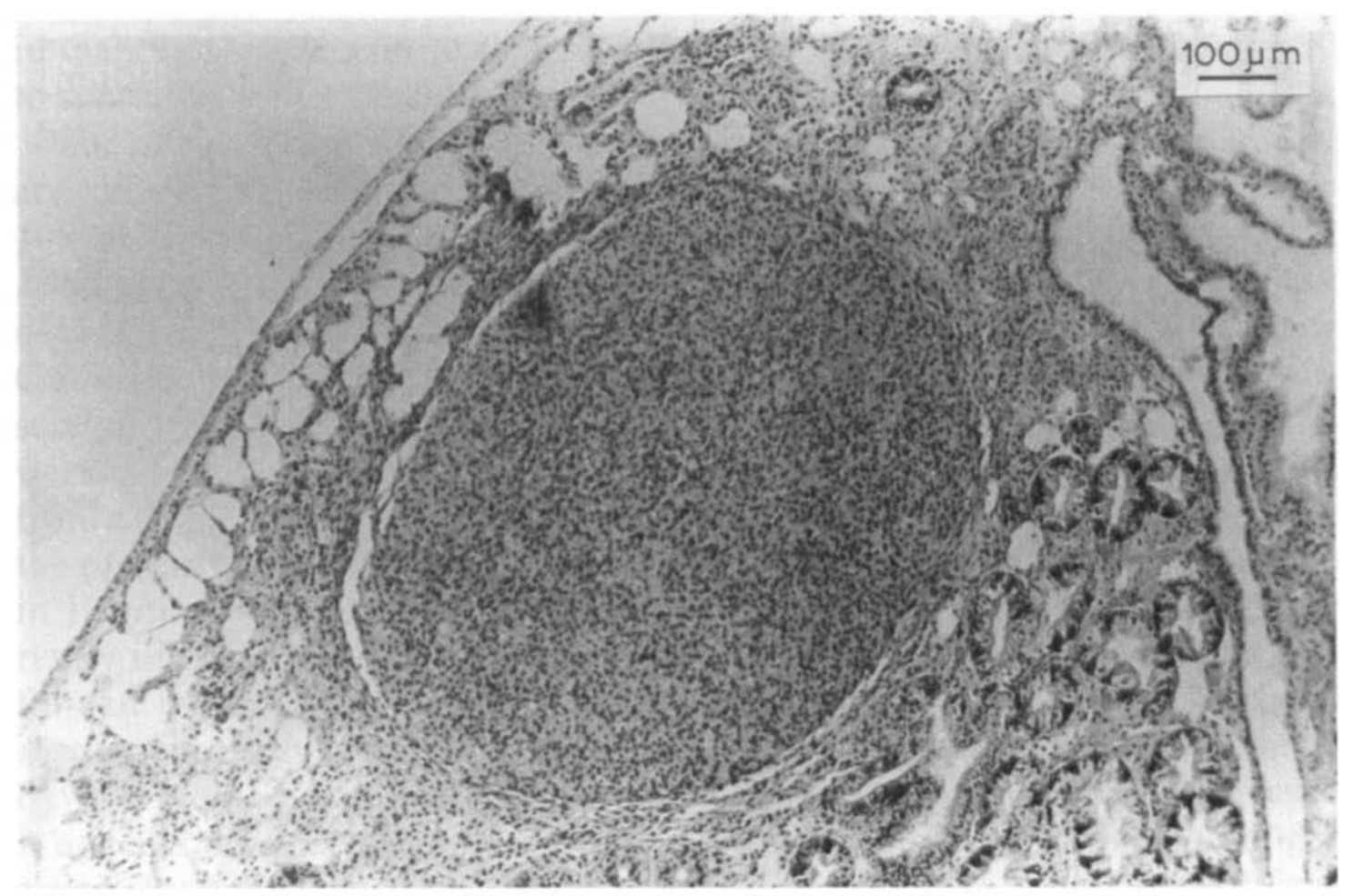

Fig. 8 


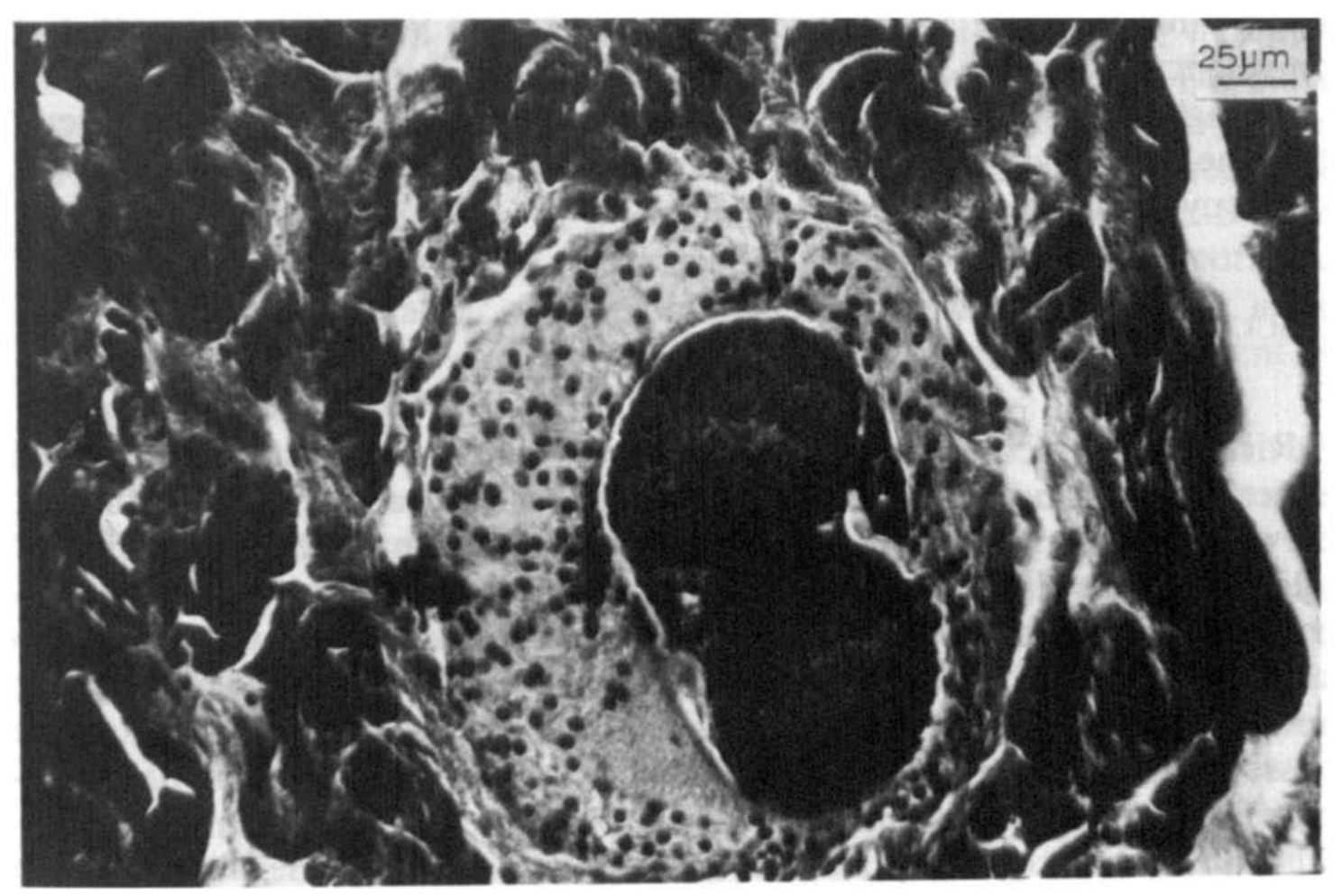

Fig. 9

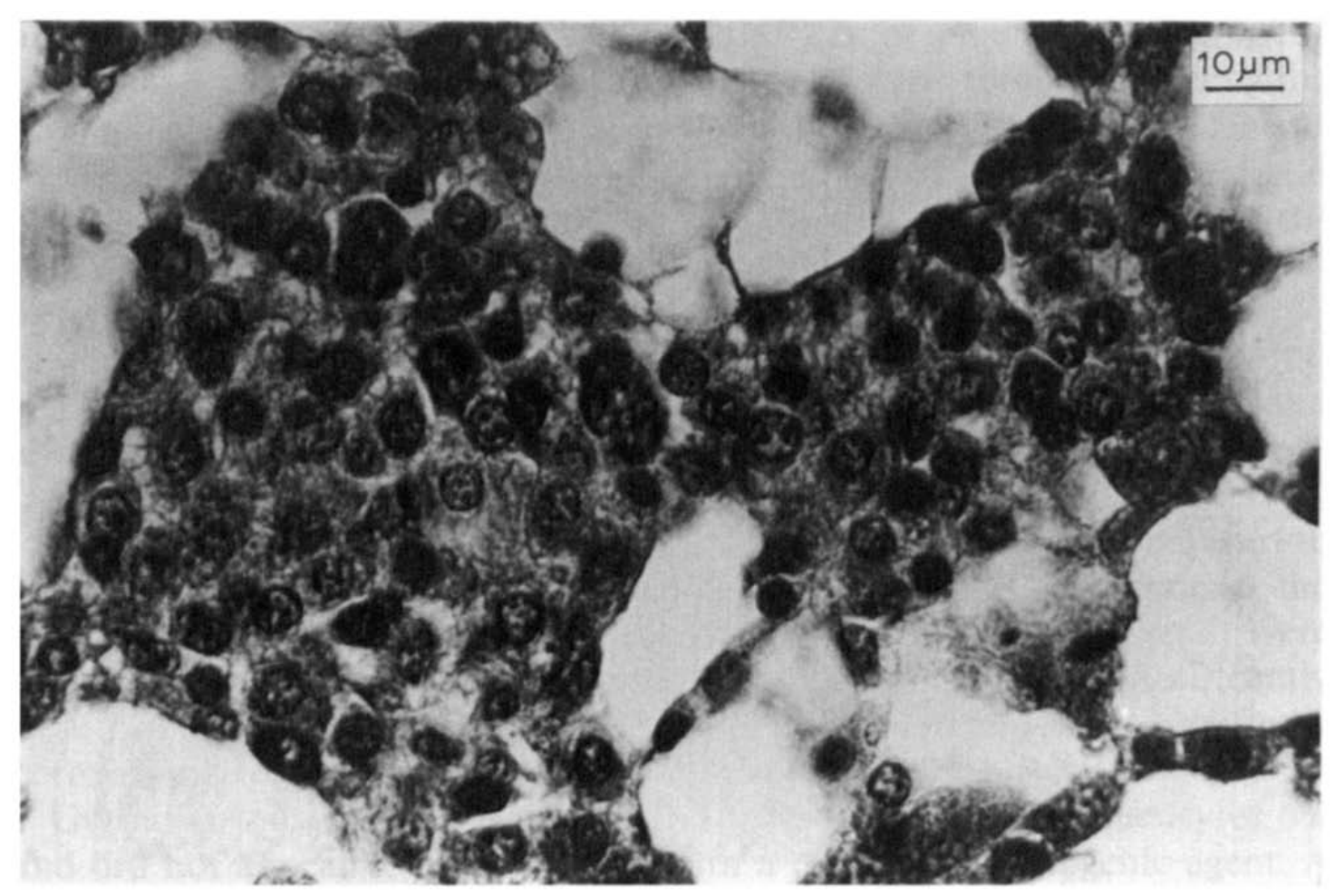

Fig. 10 